\title{
THE PRIVY COUNCIL AND THE SUPREME COURT: A JURISPRUDENTIAL ANALYSIS
}

\author{
MARK MacGUIGAN*
}

\section{INTRODUCTION}

A legal positivist unfamiliar with Canadian constitutional law might well be pardoned for thinking that the British North America Act was the ideal constitution and the Judicial Committee of the Privy Council the ideal constitutional court. The constitutional document is ideologically neutral, embodying no lofty statements of ideals and parading no value judgments. In the words of Sir Ivor Jennings, "It contains no metaphysics, no political philosophy, and no party politics." 1 The constitutional court sat out its days in judicial seclusion an ocean removed from the colony-state, with no knowledge of the geographic, economic, social, and political conditions beyond what it might gather from the London newspapers; it did not know enough about the country to choose sides in Canadian controversies. Lord Haldane was merely giving utterance to the conventional positivistic wisdom when he wrote: "We sit there, perfectly impartial; we have no prejudices, either theological or otherwise.":Such a court, reading such a constitution, should have produced a perfect positivistic product, ninety-nine and forty-four one-hundredths per cent pure. That it did not, is arguably good for the country; that it could not, is incontestably fatal for positivism.

By way of contrast, a legal sociologist would wish to point to native judicial bodies that were keenly aware of the social conditions of the nation and contended nobly with the Privy Council for the more socially beneficial rule. But unfortunately for the sociologist, while there is some evidence to support such a thesis, there is far from enough to prove it. There are, in fact, only a handful of cases which display significant disagreement between Canadian courts and the imperial court.

There were two important cases involving per saltum appeals from the Ontario Court of Appeal to the Privy Council in which strong judgments of the Ontario Court were reversed. In the Voluntary Assignments $\mathrm{Case}^{\mathrm{s}}$ in 1894 a four-to-nothing Court of Appeal decision holding that a section of the Ontario Assignments and Preferences Act was ultra vires as a transgression of the federal bankruptcy power was reversed by a Board speaking through Lord Herschell, who held that the legislation was supportable under the provincial power over property and civil

- Mark R. MacGuigan, Professor of Law, Osgoode Hall Law School, Toronto.

1 Sir Ivor Jennings, Constitutional Interpretation: The Experience of Canada (1937), 51 Harv. L. Rev. 1

2 Haldane, The Work for the Empire of the Judicial Committee of the Privy Council (1922), 1 Cam. L. Rev. 143, at 153.

3 A.-G. Ont. v. A.-G. Can. [1894] A.C. 189. Since the sociological criticism of the Privy Council is to the effect that the Board favoured Provincial power at a time when social Council is to the effect that the Board favoured Provincial power at a time when social conditions demanded a strengthening of federal power, I have cited only the cases which might support this criticism by showing a pro-provincial bias in the board. There are a number of other cases, however, in which the Privy Council overruled Canadian courts in order to Invalidate or limit provincial legislation. See, e.g., Union Colliery of ton, [1915] A.C. 330; Great West Saddlery Company, Limited v. The King, [1921] A.C. 91. 
rights. Again in Toronto Electric Commissioners v. Snider, where an Ontario trial judge and four of five judges in the Appellate Division had held that the Industrial Disputes Investigation Act was intra vires the Federal Parliament under the peace, order and good government clause on the authority of Russell v. The Queen, ${ }^{5}$ Lord Haldane's Razor decimated the federal general power to the profit of section $92(13)$. Similarly in Lymburn v. Mayland ${ }^{8}$ a unanimous judgment of the Alberta Court of Appeal holding a provincial statute authorizing investigations into fraudulent practices ultra vires as infringing the criminal law power was reversed by the Judicial Committee through Lord Atkin.

There are also two important cases in which the Privy Council reversed the Supreme Court of Canada, but they were both three-to-two decisions in the Supreme Court. In the Local Prohibition Case ${ }^{7}$ in 1896 the Privy Council through Lord Watson upheld the constitutionality of a section of the Ontario Liquor Licence Act under either section 92 (13) or section 92 (16), and in 1916, in Bonanza Creek Gold Mining Co. Ltd. v. The King, ${ }^{8}$ a Supreme Court judgment that an Ontario company had neither the power nor the capacity to carry on mining operations outside the Province was reversed by Lord Haldane. There are two further cases in which the Privy Council invalidated federal legislation where the Supreme Court had been evenly divided: The Board of Commerce Act Reference ${ }^{\vartheta}$ in 1921 and The Labor Conventions Case ${ }^{10}$ in 1937.

It could be argued from the rarity of reversals that the Canadian Courts warmly endorsed the views of the Privy Council, but such a conclusion would not be warranted by the evidence. The Supreme Court of Canada adopted a strict rule of stare decisis in the 1909 case of Stuart v. The Bank of Montreal, ${ }^{11}$ and insofar as its relationship with the Privy Council was concerned, was faithful to the spirit as well as to the letter of the rule. The early history of the Court, before the provinciallyoriented trend of Privy Council interpretation was firmly established, would also suggest the fallacy of identifying Supreme Court acceptance of the decisions of a superior Court with enthusiastic assent. In its early "independent" period up to $\mathbf{1 8 9 6}$ there was no doubt in the minds of the Supreme Court judges as to the supremacy of federal power, and the only question at issue was as to the validity of provincial legislation in the absence of federal legislation. In one of the last cases of this period Mr. Justice Sedgewick, making a plea for sociological interpretation, said: "In the British North America Act it was in a technical sense only that the Imperial Parliament spoke; it was there that in a real and substantial sense the Canadian people spoke, and it is to their language, as they understood it, that effect must be given." 12

Moreover, in later years at least one Supreme Court judge, Chief Justice Anglin, made clear over a period of time his continuing disagree-

4 [1925] A.C. 396. There was a second Ontario judge who thought the Act ultra viresOrde, J. before whom the case came on a motion for an interim injunction, which he granted.

5 (1882), 7 App. Cas. 829.

7 A.G. Ont. V. A.G. Can., [1896] A.C. 348.

8 [1916] A.C. 566 .

10 A.G. Can. v. A.G. Ont., [1937] A.C. 326.

10 (1909). 41 S.C.R. 516.

12 In re Prohtbiting Ltquor Laws (1895), 24 S.C.R. 170, at 231. 
ment with the Privy Council. In the Insurance Act Reference ${ }^{13}$ in 1916 he advocated an interpretation of the general power in terms of "national concern" which on appeal fell afoul of Haldane's Razor. In the Board of Commerce Act Reference ${ }^{14}$ in 1921 he took the view that the federal legislaion there could be upheld under both the general power and the trade and commerce clause, but Lord Haldane took a contrary view. The Supreme Court had no opportunity to express an opinion in the Snider Case, but in a later case the same year Chief Justice Anglin (dissenting) took strong exception to Haldane's "emergency doctrine" interpretation of the general power. ${ }^{15}$

However, if from the evidence one cannot read internal assent into the external compliance of the Supreme Court, still less can one conclude to colonial judicial disaffection. Canadian Courts themselves did not seem to be alive to sociological factors. Indeed, to take the fate of the Canadian "new deal" legislation as an example, with the exception of the Labor Conventions Acts (on which there was a three-to-three split in the Supreme Court of Canada), the Privy Council decided the other references in the same way as had the Supreme Court, save that in three instances the Privy Council was slightly more favorable to the federal legislation than the Supreme Court had been. Moreover, the judge who is considered by many to be our greatest native jurist, Sir Lyman Duff, appeared not merely to follow in the footsteps of the Board but to break new ground for the benefit of provincial rights. In many instances his concepts were taken up by the Privy Council, ${ }^{16}$ and Professor Laskin has not hesitated to pronounce that, "Sir Lyman showed, as early as the Board of Commerce case, that he had embarked on that course [of interpretation with respect to the general power] as much by his own choice as by the dictates of stare decisis." 1 .

\section{ESSENTIALISTIC NATURAL LAW APPROACH}

To this point, it has been suggested, but not proved, that the approach of the Privy Council to the Canadian Constitution cannot be adequately explained either in terms of positivism or of sociologism. A third possibility might be raised: that their approach was essentially a naturallaw one and that, as a converse to the establishing of this thesis, it was neither positivistic nor sociological.

It is not necessary, in order to establish a natural-law approach, to demonstrate that the Board considered certain things to be taboo for both national and regional governments, though Dean Scott has drawn attention to the fact that generally the Board found ultra vires all statutes attempting to control trade and commerce, whether they were federal or provincial. ${ }^{18}$ It is sufficient, however, to show that the Law Lords indulged in extensive judicial legislation, and that the source of their legislative wisdom was not the clamor of the colonial populace, nor

18 (1916), 48 S.C.R. 260, at 310; [1916] 1 A.C. 588, at 595.

$14(1920) ; 60$ S.C.R. 456; [1922] 1 A.C. 191.

15 The King v. Eastern Terminal Elevator Co., [1925] S.C.R. 434, at 438.

16 Several instances are cited by Bora Laskin (now Laskin, J.A. of the Ontario Court of Appeal), The Supreme Court of Canada: A Final Court of and for Canadians (1951), 29 Can. Bar Rev. 1038, at 1067-9.

17 Laskin, Peace, Order and Good Government Re-Examined (1947), 25 Can. Bar Rev. 1054,

18 F. R. Scott, The Consequences of the Privy Council Decisions (1937), 15 Can. Bar Rev. 485 , at 492 . 
even their own observation of the actual exigencies of the society, but rather an abstract and pre-existing concept of federalism which they applied like a procrustean bed to the ungainly limbs of the adolescent statute. Such an essentialistic use of natural-law theory is one toward which the contemporary natural lawyer feels no more kinship, than he does toward the laissez-faire natural law epoused by the U.S. Supreme Court a few decades ago; but he can hardly deny the validity of the technique, even if he quarrels with the content of the doctrine.

The introductory clause of Section 91, the so-called general power, gives the Parliament of Canada the right "to make laws for the Peace, Order, and Good Government of Canada," and this is the only grant of legislative power given to Parliament. However, "for greater certainty, but not so as to restrict the generality of the foregoing terms" Parliament is given exclusive legislative authority over twenty-nine enumerated classes of subjects. Section 92 then assigns to the Provincial Legislatures legislative power over sixteen enumerated classes of subjects. The scheme of the Act clearly suggests the supremacy of federal power and that the peace, order, and good government clause is properly to be interpreted as a grant of residuary legislative power.

There can be no doubt that this was also the intention of the Fathers of Confederation. In the Confederation debate in the Parliament of Canada in 1865 John A. Macdonald maintained: "We have strengthened the general government. We have given the General Legislature all the great subjects of legislation." 19 In a similar vein Lord Carnarvon, the Secretary of State for the Colonies, told the House of Lords: "Just as the authority of the central Parliament will prevail whenever it may come into conflict with the local legislatures, so the residue of legislation, if any, unprovided for in the specific legislation ... will belong to the central body."20

What the Privy Council did with the Constitution is another story. ${ }^{21}$ In its early period, from 1873 (when the first Privy Council appeal from Canada was decided) until 1894, there was no strong trend in the direction of either the Provinces or the Dominion. The main desire of the Board sems to have been to uphold all legislation brought before it, though this undoubtedly implied a failure to emphasize the paramount position of the Federal Government to the extent intended by the Fathers. The most important cases in this period were Russell v. The Queen, ${ }^{22}$ which upheld federal regulation of the liquor traffic under the general power, and Hodge v. The Queen, ${ }^{22}$ in which provincial liquor legislation not essentially different from the federal legislation approved in the Russell case was upheld.

The next period, from 1894 to 1906, saw the dominance of Lord Watson in the years up to 1899. During that time he was a member of the Board in all nine constitutional cases and gave the opinion five times; Lord Herschell gave the opinion three times, and Lord Halsbury once. After 1899 Lord Halsbury gave the opinion in the only two constitutional

19 The Confederation Debates, ed. Waite, 44 (1963).

20 Hansard, vol. 185, cols. 563, 566.

21 My review of Privy Council activity is based in part upon that of Jennings, ante, $n .1$.

22 (1882) 7 App. Cas. 829.

28 (1883), 9 App. Cas. 117. 
cases. The most important case in this period is probably the Local Prohibition Case ${ }^{24}$ in 1896, in which Lord Watson began the whittling down of section 91, and especially of the general power.

The years 1907 to 1912 were transitional in terms of court personnel, and there were no crucial cases during this time. Then in 1912 Lord Haldane, who had been active as counsel in Canadian appeals since 1885, appeared for the first time, and from then until 1929 he was the dominant personality on the Board. In those years there were Forty-one decisions on legislative power; Lord Haldane was present on thirty-two occasions and delivered the opinion nineteen times. Of the many important cases in this period only two will be mentioned: the Board of Commerce Act Reference $^{25}$ in 1921 and the Snider Case ${ }^{26}$ in 1925. By means of the Board of Commerce Act the Dominion was attempting to regulate retail prices, and endeavored to sustain this regulation under both the general power and the trade and commerce clause. In the course of his opinion Lord Haldane said that the general power can justify interference with property and civil rights only "in highly exceptional circumstances." $\mathrm{He}$ also held that the commerce clause could not of itself sustain legislation, but could merely have the effect of aiding jurisdiction under the general power; thus in fact it was denied independent existence as a head of section 91 .

In the Snider Case in striking down a federal act which had been in effect for nearly twenty years, Lord Haldane declared: "Their Lordships think that the decision in Russell v. The Queen can only be supported today ... on the assumption of the Board, apparently made at the time of deciding the case of Russell v. The Queen, that the evil of intemperance at that time amounted in Canada to one so great and so general that at least for the period it was a menace to the national life of Canada so serious and pressing that the National Parliament was called on to intervene to protect the nation from disaster. An epidemic of pestilence might conceivably have been regarded as analogous."

The next period, 1929 to 1935, coincides with the years of England's first Labour Government and the reign of Lord Sankey as Lord Chancellor. With his famous "living tree" metaphor in the Edwards Case" Lord Sankey suggested the possibility of a new approach to the Constitution, and in the four following cases (the P.A.T.A. Case, ${ }^{30}$ the Aeronautics Case, ${ }^{31}$ the Radio Case, ${ }^{32}$ and the British Coal Corporation Case) ${ }^{33}$ the decisions went in favor of the Federal Government.

The late period of Privy Council activity, stretching from 1935 to 1953, began with the 1937 new deal references, in which the Board reverted to a limited view of federal power, and ended with a number of postwar cases in which the Board took a more benign view of federal power. Of the eight new deal acts considered by the Privy Council, five were held completely ultra vires, one was held partly ultra vires, and

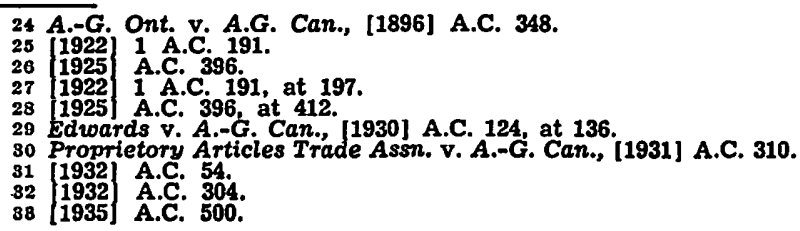


two were upheld. ${ }^{34}$ The statutes wholly struck down were the three Labour Conventions Acts passed to enable Canada to discharge her obligations under the Treaty of Versailles and related draft conventions, the Employment and Social Insurance Act, which established a national unemployment insurance scheme, and the Natural Products Marketing Act, which established a national marketing board to regulate marketing and distribution. The result respecting unemployment insurance was rectified by a 1940 amendment to the B.N.A. Act, but the disallowance of the other acts remained a serious blow to the National Government. In the Natural Products Marketing Act Reference ${ }^{35}$ the Privy Council took the view that neither the peace, order, and good government power nor section 91 (2) could sustain the legislation, and in the Labour Conventions Reference ${ }^{36}$ it held that the acts could be based neither on the introductory clause of section 91 nor on section 132 . In sum, the result of the cases to the beginning of World War II was that the commerce clause had no meaning at all, and that the general power gave Parliament the right to make laws only for the emergencies of war, famine, or pestilence, for the incorporation of companies having national objects, and for the regulation of communication by radio.

Subsequently in the 1946 Canada Temperance Federation Case, ${ }^{37}$ where the Privy Council was asked to consider again substantially the same statute approved in Russell v. The Queen, Viscount Simon refused to accept Lord Haldane's emergency doctrine and upheld the statute under the general power, stating: "it is the nature of the legislation itself, and not the existence of emergency, that determines whether it is valid or not." ${ }^{38}$ And in the Reference re Privy Council Appeals ${ }^{39}$ the following year Viscount Jowitt, like Lord Sankey before him, chose to treat the British North America Act as a constitution rather than as an ordinary statute.

This has been too cursory a survey of the cases to establish any substantive point of constitutional law, but it serves perhaps to illustrate the method of interpretation. Twenty-five years ago Dean Kennedy argued that in not one case "has the ratio decidendi [of a Privy Council decision] depended on reasons external to the Act," 40 but this is surely true only in a formal sense. The Privy Council no doubt always found words in the Act on which to rest its interpretation, but there was nothing inevitable about the solutions, not even in terms of the accumulated precedents. To take just two examples, the Insurance Act Reference and the Labour Conventions Reference could have been decided in the opposite way even by a court which genuinely accepted the precedents. (Indeed, in the former case Lord Haldane was himself unable to cite any precedent to support his drastic limitation of the general power). Moreover, the foregoing survey has shown that interpretation has varied with the composition of the Board, with some relief from provincial supremacy in the early thirties and in the middle forties.

34 I am indebted to the complete analysis of the new deal references in Vincent C. MacDonald, The Canadian Constitution Seventy Years After (1937), 15 Can. Bar Rev. 401.

35 A.-G. B.C. v. A.-G. Can., [1937] A.C. 377

36 A.-G. Can. v. A.G. Ont., [1937] A.C. 326

37 A.-G. Ont. v. Canada Temperance Federation, [1946] A.C. 193.

$38 \mathrm{Id}$, at 205.

39 A.-G. Ont. v. A.-G. Can., [1947] A.C. 127.

40 W. P. M. Kennedy, The Constitution of Canada, and ed., 550 (1938). 
Over the years the Privy Council established many doctrines to help them interpret the constitution: the paramountcy doctrine, the trenching doctrine, the ancillary powers doctrine, the occupied field doctrine, the pith and substance doctrine, and the aspect doctrine. But these doctrines were merely the implements of the lawyers' craft; they were the tools by which the Law Lords rationalized their conclusions, but they were not the instruments for reaching the conclusions. In essence what the Privy Council had to decide was what meaning and purpose to assign to the whole Act and what meaning and purpose to ascribe to the relevant parts of sections 91 and 92; neither of these tasks is at bottom predetermined by logic or precedent. The ultimate decision had to be a value judgment, or, if you prefer, a policy decision.

That the Privy Council itself had no illusions on this score is indicated by these words of Lord Haldane, spoken in 1921:

At one time, after the British North America Act of 1867 was passed, the conception took hold of the Canadian courts that what was intended was to make the Dominion the center of government in Canada, so that its statutes and its position should be superior to the statutes and position of the Provincial Legislatures. That went so far that there arose a great fight; and as the result of a long series of decisions Lord Watson put clothing upon the bones of the Constitution, and so covered them over with living flesh that the Constitution of Canada took a new form. The Provinces were recognized as of equal authority co-ordinate with the Dominion, and a long series of decisions were given by him which solved many problems and produced a new contentment in Canada with the Constitution they had got in 1867. It is difficult to say what the extent of the debt was that Canada owes to Lord Watson, and there is no part of the Empire where his memory is held in more reverence in legal circles. ${ }^{1}$

Lord Haldane here proves himself a poor prognosticator: with the emergence of the law teaching profession and the consequent development of legal writing in Canada in the twenties and thirties, discontent with the Constitution proved almost boundless, and if there is any name less revered in Canadian legal circles than that of Lord Watson it is only that of Lord Haldane himself. But his statement is a frank enough admission of judicial legislation: the "new form" which Lord Watson gave the Canadian Constitution was painly in Lord Haldane's mind not dictated by the bare bones of the text, and in his opinion but for Lord Watson's heroic fattening job the Constitution might have remained a mere skeleton.

Fault can be found with the Watson-Haldane axis not on the score of judicial legislation, nor even primarily on the score of favoritism towards the provinces. Their failure was not that they legislated, nor even so much what they legislated, but rather how they legislated. Their failure was to view the Constitution too abstractly and therefore to rely on a formalistic and formularistic natural law.

\section{Some years ago Professor Freund wisely remarked:}

If the first requisite of a constitutional judge is that he be a philosopher, the second requisite is that he be not too philosophical. Success in the undertaking requires absorption in the fact rather than deduction from large and rigidly held abstractions. The constitutional judge is an architect, one who tempers the vision of the artist with a reliable knowledge of the strengths and weaknesses and availability of materials. 42

11 Ante, n. 1, at 150.

12 P. A. Freund, Umpiring the Federal System (1954), 51 Col. L. Rev. 561, at 574. 
Lord Haldane more than once proclaimed his devotion to Hegelian dialectic, which is characterized not only by great abstractness, but also by the inevitability of historical process through a conflict of thesis and antithesis. In such an intellectual universe how easy it is to see the Dominion principle and the provincial principle as exclusive opposites plunged inevitably into dialectical struggle, how noble it is to feel the need to assist the weaker so that the eternal struggle could continue.

The result of the application of such an essentialistic natural-law doctrine to the Canadian Constitution was an insoluble dilemma for the Privy Council. On the one hand, by treating the B.N.A. Act as an ordinary statue and not as a constitutional document, by giving consideration neither to the historically documented intention of the Fathers nor to the exigencies of the present as revealed through such devices as Brandeis Briefs, by insisting that nothing can aid decision but the words of the statute itself, it deliberately thrust itself into a positivistic vacuum excluding everything but form and formula. But on the basis solely of such a process of pure textual interpretation it could not possibly have reached a result so far removed from the clearly expressed structure and meaning of the Act. Thus, to delineate the other horn of the dilemma, the Board found with experience that it did not really want to give merely a literal interpretation to the Act, even that it could not do so. Forced by the pressure of reality into making policy, it was at the same time compelled by the logic of its own position to make policy in complete abstraction from the socio-economic needs of the people; unable to feed on facts, it had to dine on transcendentals. In sum, even without the aid of a Bill of Rights, the Privy Council found it possible to give a natural-law cast to the Canadian Constitution, but unfortunately it was a dull, abstract, essentialistic natural law.

\section{CANADIAN FEDERALISM}

Thus far the substantive aspect of constitutional law held up for examination has been the question of distribution of legislative powers, which resolves itself into the policy issue whether the Court should favor the national power or the provincial powers. But more fundamental even than the distribution of legislative power is the conception of federalism which underlies it. Canadian Confederation was conceived in terms of classical federalism, which considered the national and regional governments as independent and autonomous entities-though in the Canadian case with the modification that the greater sovereignty should be given to the central government. The individualism and laissez-faire which gave birth to classic federalism assumed that, since there would be a minimum of government at both levels, there would be little prospect of collision, but the facts of life soon showed that this was an unrealistic expectation.

The Privy Council decided early to adopt the model of classical federalism-though without provision for federal dominance as intended by the Fathers. As early as 1883 it established the complete equality of status between Parliament and the Provincial Legislatures, neither being inferior or subordinate to the other. As Lord Watson proclaimed in 1892: "The object of the Act was neither to weld the provinces into one, nor 
to subordinate the provincial governments to a central authority, but to create a federal government in which they should all be represented, entrusted with the exclusive administration of affairs in which they had a common interest, each province retaining its independence and autonomy." 43

Over the years their Lordships continued to assume a state of constant conflict between Parliament and the Legislatures (an assumption not entirely at variance with the facts), but the full effects of the fundamental principle were not seen until the Natural Products Marketing Act Reference in 1937. The Act in question there provided for the establishment of a national marketing board to regulate marketing and distribution, and it also provided for the exercise by the board of any powers that might be conferred upon it by provincial legislatures. The Federal Government, having accomplished the miraculous feat of surmounting the technical, legal, and political difficulties in the way of provincial cooperation, found itself faced with a Privy Council declaration of ultra vires, despite the fact that all nine provinces had supported the plan, and that all had actually enacted special legislation to confer powers on the federal marketing board. Verbally sympathetic to the concept of cooperation, the Court commented that the desired aim "will not be achieved by either party leaving its own sphere and encroaching upon that of the other".44

A sociological analysis of Canada in the thirties would, it is suggested, show the inutility of the Privy Council decisions at that time. The conduct of international relations by the Federal Government had been seriously interfered with; Canada actually had much less power to implement treaties by legislation than it had had under section 132 in the days when the Mother Country entered into all treaties on her behalf. Many matters of national importance had been placed beyond the legislative competence of Parliament. The Provinces, which had been the beneficiaries of the legislative bounty of the Privy Council, did not have the financial resources to deal effectively with the subjects under their jurisdiction. The results seemed so unfortunate at the time that one observer wrote, "Confederation itself may well have difficulty in surviving the disintegrating effect of the Court's judgments upon the B.N.A. Act."

But cooperative federalism could not be stopped by the courts. The depression, the War, the increasing industrialization, the tax rental agreements, the new budgetary policy all pushed the country inexorably into cooperative federalism, and a large part of the work of the Supreme Court since 1949 has consisted in the legal establishment of the cooperative principle. In the economic field, when the question of dovetailing federal and provincial statutes came before the newly emancipated Court in 1951 in the Nova Scotia Delegation Reference, ${ }^{46}$ it took the same narrowly legalistic approach as the Privy Council, holding that since both Parliament and the Provincial Legislature were sovereign bodies with exclusive jurisdiction, each was incapable of delegating to the other and

43 The Liquidators of the Maritime Bank of Canada v. The Receiver-General of New Brunswick, [1892] A.C. 437, at 442 (emphasis added).

44 [1937] A.C. 377 , at 380 .

46 Scott, ante, n. 18 , at 484

46 A.-G. N.S. v. A.-G. Can., [1851] S.C.R. 31. 
of receiving delegated power from the other. Subsequently, however, in the P.E.I. Potato Marketing Board Case ${ }^{47}$ the Court felt able to approve the delegation of federal powers to a provincially created and controlled board, thus providing a solution to one of the problems of economic cooperation. In the field of criminal law, even before 1949 the Supreme Court showed a considerable tolerance of nearly identical legislation as in the $\operatorname{Egan}^{48}$ case, and recent decisions such as O'Grady v. Sparling ${ }^{49}$ promise a continuance of the same trend. It is submitted that this trend in criminal law is to be welcomed, and that it would be all to the good if a constitutional conference made criminal law constitutionally what it is in fact, viz. a field of concurrent federal and provincial jurisdiction, provided that this was accompanied by a clear recognition of federal jurisdiction over civil liberties.

At the outset cooperative federalism had a decided federal biasnot because of anything in the law, whether legislative or judicial, but rather because of the realities of economic and political power (which precede rather than follow the law). For this reason it is a bad word and a bad idea in the minds of many French-speaking Canadians.

But today cooperative federalism has in truth a decided provincial bias. The reasons are many: the polticial strength of the provincial governments, the political weakness of minority federal governments, the years of recession and of unbalanced federal budgets, the development of closer liaison between the provincial governments and the possible emergence of a third form of government, viz., the continuing FederalProvincial Conference, and perhaps most of all the dynamism of the Quebec Revolution. The point is, however, that the bias in cooperative federalism will be taken care of by non-legal factors. The law should go on further than to reflect the desire of the people and the necessity of the times for cooperative federalism. It may be that as part of its task of umpiring the federal system the Court will be called upon to decide the boundaries in areas of conflict, but it should be slow to rush into economic controversies. If the Court adopts generally a hands-off policy in the economic area, it will find that most of the work of striking a balance is done for it by other forces. ${ }^{50}$

\section{CONCLUSION}

A discussion of the great question of constitutional reform is not within the scope of this article. The concern is not with the new Confederation Pact, but with what the Court will do with it, if it comes about. It too will age and require a bringing up to date. Even in its early years it will require interpretation as all written documents are wont to do.

This article is almost concluded and very little has been said about the role of the Supreme Court of Canada. Yet implicitly continuing reference has been made to it. The opinion advanced is that it should not continue the positivistic fiction of pretending that everything but the words of the constitution is irrelevant to its interpretation; and that it

\footnotetext{
$47[1952]$ 2 S.C.R. 392.

48 1941] S.C.R. 396.

$49[1960]$ S.C.R. 804.

60 would, however, argue that it should adopt a much more active policy in defence of civil liberties, which I regard as having a preferred position among human liberties.
} 
should embrace a sociological or a sociological natural-law approach and the means necessary for the success of such an approach. Only a contemporary-minded Court can keep a constitution contemporary, and a constitution which is not contemporary will prove to be merely temporary.

With a sociological approach there is, of course, the danger of bad policy judgments, which would probably be understood to mean ones with which we are not in sympathy. But is it preferable to have ultimate decisions made by a court without sociological knowledge which are sure (except for accidental coincidences) to be the wrong solutions, or is it preferable to have decisions made by a sociologically conscious court which have at least a possibility of being the best solutions? On the answer to this question will depend the future role of the Supreme Court. 